\title{
Meta-analysis of the relationship between montelukast use and neuropsychiatric events in patients with allergic rhinitis and/or asthma
}

\author{
Qing Song ${ }^{1}$, Kui Mu², Yao Yao², Juan Yang², Hua Zhang², and cheng song ${ }^{2}$ \\ ${ }^{1}$ Weifang Medical University \\ ${ }^{2}$ Qindao University Medical College Affiliated Yantai Yuhuangding Hospital
}

May 26, 2020

\begin{abstract}
There is controversy over whether the use of montelukast increases neuropsychiatric events (NEs) in patients with asthma and allergic rhinitis. Our objective was to evaluate whether montelukast caused an increase in neuropsychiatric adverse reactions compared with placebo. We conducted a systematic review and meta-analysis to explore the relationship. The main result of the study was the incidence of NEs. Fifteen RCTs were screened and included for meta-analysis to merge statistics. The main results showed no significant increase in NEs compared with the placebo group. Similar results were seen in the occurrence of NEs in patients grouped by age and headache that the most common neuropsychiatric adverse event. Overall, montelukast did not significantly increase NEs in patients with AR and/or asthma compared with placebo.
\end{abstract}

\section{INTRODUCTION}

Montelukast is one of the widely used leukotriene receptor antagonists, which can alleviate the symptoms of allergic diseases, such as asthma and allergic rhinitis, and improve the prognosis of patients by reducing the production of inflammatory mediators. ${ }^{1-3}$ Montelukast can be used in adults and children. However, with its widespread use, the occurrence of neuropsychiatric events (NEs) in patients taking montelukast increases significantly. ${ }^{4-14}$

Considering the pharmacovigilance studies ${ }^{4-6,8,11-14}$ and case reports ${ }^{7,9,10}$ of neuropsychiatric adverse reactions, the US Food and Drug Administration (FDA) adds a warning for NEs to the montelukast label. Before using montelukast, patient's condition should be considered comprehensively, considering whether the patient has depression, headache, anxiety, insomnia, aggression, suicidal ideation, or behavioral neuropsychiatric adverse reactions. ${ }^{15,16}$ However, these warnings are not taken seriously, and the mental state of the patient is not considered when the montelukast envoy is present. In 2020, the FDA has issued the following black box warning: limit the use of allergic rhinitis unless the patient is ineffective or unable to tolerate other clinical drugs and asthma patients should be fully considered before using montelukast. ${ }^{17}$

However, conflicting research has been found on the relationship between NEs and montelukast. Studies have shown that patients who use montelukast have a high occurrence of NEs, whereas others have found that the occurrence of NEs is not related to the use of montelukast. ${ }^{4-14}$ No statistical analysis was found on the relationship between NEs and montelukast. ${ }^{18} \mathrm{As}$ such, the purpose of this article is to illustrate the relationship between NEs and montelukast through high-quality randomized controlled study results.

\section{METHODS}




\section{Search strategy}

We conducted a comprehensive survey of patients with allergic rhinitis and/or asthma who used montelukast to analyze the possibility of NEs. MEDLINE (1966 to March 2020), Embase (1974 to March 2020), Web of Science databases, and reference lists of the retrieved studies were used. The search formula used was as follows: montelukast and drug-related side effects and adverse reactions.

Inclusion criteria and trial selection

Studies were included if they met the following criteria: (i) montelukast was used to treat patients with allergic rhinitis and/or asthma; (ii) randomized controlled trials; (iii) full text could be found online and published in English language; (iiii) the study provided available data for analysis. The selection process of included studies was shown in the flow chart (Figure 1).

Quality assessment

The quality of the included studies was assessed by Jadad scale. ${ }^{19}$ Each study can be assessed by methods (method of patient random allocation, concealment of allocation, blinding and data loss to follow). Afterward, the Cochrane Handbook for Systematic Reviews of Interventions v.5.1.0. ${ }^{20}$ was used to grade individual studies. Each study was assigned a category: A, low risk of bias where the study met almost the criteria; B, moderate risk of bias where the study met part or unclear for one or more quality criteria; C, high risk of bias where the study did not meet or included the criteria. Differences were resolved by discussion among the authors.

Data extraction

The measurable data were collected from the included study: (1) first author name, (2) publication year, (3) name of disease and type of design, (4) the sample number and patients' age, (5) the therapy that the patients in the experimental group received, (7) the sample number of NE occurrence and the type of NEs, (8) follow-up period.

Statistical analysis

The STATA 12.0 package (StataCorp, College Station, TX, USA) was used to analyze the data. Fixed or random-effect models will be used to combine statistics. The relative risk (RR) was used to estimate dichotomous outcomes and the $95 \%$ confidence interval (CI). I2 test and x2-based Q statistics were used to assess the heterogeneity of the study. If I 2 value $>50 \%$ or p-value $<0.1$, then the heterogeneity of the study was significant, and the fixed-effect model was used to analyze the study. Otherwise, the random-effect model was used. If p-value was less than 0.05 , then the result was considered statistically significant.

\section{RESULTS}

Characteristics of individual studies

We found 574 articles in the database and reference lists. After eliminating duplicate articles, 460 articles were included for further analysis. Based on reading of title and abstract, 418 articles were excluded. Finally, we selected 13 articles ${ }^{1,21-32}$ containing 16 RCTs for meta-analysis after reading the full text. The screening process and the characteristics of each included study are shown in Figure 1 and Table 1, respectively.

Quality of individual studies

All studies were randomized controlled studies and calculation of sample size. Three studies ${ }^{22,31,32}$ containing four RCTs did not explain the random method, and one study did not explain the blind method; Jadad scores were rating B. One study ${ }^{32}$ containing two RCTs were rating $\mathrm{C}$ without blinding. Five studies $^{24,25,28,31,32}$ containing seven RCTs did not used intention-to-treat analysis. Consequently, the quality level of two RCTs of one study was C, and the quality level of three studies ${ }^{22,28,31}$ was B; the rest of the studies $^{21,23-25,27,28}$ containing RCTs with Jadad scores were A. (Table 2). Bruce et al. ${ }^{32}$ reported that the 
Jadad level was $\mathrm{C}$, which indicated a high risk in the study and might cause a bias to the results if included in the meta-analysis. Therefore, we did not include this study in the following analysis.

$\mathrm{NE}$

3.31 The occurrence of NEs in a randomized placebo-controlled study

Ten RCTs ${ }^{1,21-27,29,31}$ that enrolled 3721 patients (2262 in the montelukast group and 1459 in the placebo group) were used to access the occurrence of NEs in patients with allergic rhinitis and/or asthma. No significant heterogeneity ( $2<50 \%, \mathrm{P}>0.1$ ) was found in our research. Therefore, we used the fixed-effect model to consolidate the statistics, and risk ratio (RR) was used to assess the size of the effect (Figure $2 \mathrm{~A})$. The forest plot showed no statistical significance $(\mathrm{RR}=0.88,95 \% \mathrm{CI}=0.74-1.06, \mathrm{P}=0.18>0.05)$ between the NEs in the experimental and control groups. This finding indicated that the use of montelukast did not increase the incidence of NEs in patients with allergic rhinitis and/or asthma. We developed a funnel plot to assess the publication bias of NEs in patients receiving montelukast or placebo, which presented a symmetrical appearance and was not statistically significant (Begg test, $\mathrm{P}=0.86$; Egger test, $\mathrm{P}=0.67$ ), showing a low publication bias (Figure 2B).

\subsection{Headache-related NEs}

Nine $\operatorname{RCTs}^{1,21-27,31}$ that enrolled 3393 patients (2098 in the montelukast group and 1295 in the placebo group) were used to access the occurrence of headache, the most common event in NEs. No significant heterogeneity was found; thus, we used the fixed-effect model $(\mathrm{RR}=0.87,95 \% \mathrm{CI}=0.71-1.06, \mathrm{P}=0.177>0.05$; Figure 3). The result indicated that no statistical significance was found between the montelukast group and placebo group for the occurrence of headache.

$3.33 \mathrm{NEs}$ in patients with asthma or AR

Asthma and AR were the common chronic inflammatory diseases. Six RCTs ${ }^{21-24,27,29}$ that enrolled 2115 patients (1331 in the montelukast group and 784 in the placebo group) included data on the occurrence of NEs in asthma patients. The study indicated that no statistically significant difference was found between the montelukast group and placebo group $(\mathrm{RR}=0.86,95 \% \mathrm{CI}=0.713-1.05, P=0.13$; Figure $4 \mathrm{~A})$. Three $\mathrm{RCTs}^{25,26,31}$ evaluated the adverse reactions of montelukast in $993 \mathrm{AR}$ patients (620 in the montelukast group and 373 in the placebo group). This result suggested that no increase in NEs in patients with allergic rhinitis who received montelukast compared with the placebo group $(\mathrm{RR}=1.04,95 \% \mathrm{CI}=0.55-1.98, P=0.91$; Figure 4B).

\subsection{NE in children or adults}

Eight RCTs ${ }^{1,22-27,29}$ that enrolled adult 2972 patients (1781 in the montelukast group and 1191 in the placebo group) were used to estimate the occurrence of NE. The forest plots of the fixed-effect model indicated a RR of 0.87 and $95 \% \mathrm{CI}$ of 0.71 to $1.06(P=0.16$; Figure $5 \mathrm{~A})$. No statistically significant difference was found in the two groups. Two RCTs with 749 child patients evaluated the occurrence of NEs (481 in the montelukast group and 268 in the placebo group). Based on the fixed-effect model, the result showed the number of NE without increase in child patients taking montelukast compared with placebo $(\mathrm{RR}=0.97,95 \% \mathrm{CI}=0.64-1.5, P$ $=0.9 ;$ Figure $5 \mathrm{~B})$.

\subsection{Relationship between NE and montelukast or common clinical drugs}

Four RCTs ${ }^{25,26,28,30}$ that enrolled 875 patients (437 in the experimental group and 436 in the control group) were used to access the occurrence of NE in patients with allergic rhinitis and/or asthma. We made a funnel plot to evaluate publication bias. A symmetrical appearance indicated a low publication bias (Begg test, $P=0.73$; Egger test, $P=0.75$; Figure $6 \mathrm{~A}$ ). Two RCTs ${ }^{23,24}$ were used to compare the NEs in patients taking budesonide with patients taking montelukast. No heterogeneity was found $\left(\mathrm{I}^{2}<50 \%\right)$. Thus, a fixedeffect model was used. This result showed no statistically significant difference $(\mathrm{RR}=4.0,95 \% \mathrm{CI}=0.47-34$, $P=0.21$; Figure $6 \mathrm{~B}$ ). The remaining two RCTs with 785 patients (392 in the experimental group and 393 in the control group) were used to compare the incidence of NEs in patients taking loratadine with that 
taking montelukast. The heterogeneity test result was $\mathrm{I}^{2}=60.7 \%>50 \%, P>0.1$. A random-effect model was used to combine the effect; RR was 0.39 , and $95 \%$ CI was 0.07 to 2.18 ( $P=0.29$; Figure $6 \mathrm{C})$. Furthermore, montelukast combined with loratadine likely have an NE than loratadine.

\section{DISCUSSION}

Asthma and allergic rhinitis are common allergic diseases with high occurrence. Clinically, montelukast is used in the treatment of asthma and allergic rhinitis. ${ }^{33,34}$ Montelukast was approved by the FDA in 1998 for the treatment of asthma and in 2002 for the treatment of allergic rhinitis, but long-term use of montelukast could cause neuropsychiatric adverse reactions. ${ }^{33} \mathrm{FDA}$ added NEs to adverse drug reactions in 2009, and with the increase in reports of NEs, FDA strengthened existing warnings about serious behavior and mood-related changes with montelukast on March 4, 2020. ${ }^{15-17}$

However, only pharmacovigilance studies ${ }^{4-6,8,11-14}$ and case reports7,9,10 have shown the relationship that montelukast could cause neuropsychiatric adverse reactions. High-quality randomized controlled studies have not been comprehensively analyzed. Therefore, the purpose of this meta-analysis is to compare whether the use of montelukast could cause NEs in patients with asthma, rhinitis, or both. Ten articles 1,21-26,29,31 and 3721 participants were included in our meta-analysis. The results indicated no statistical significance $(\mathrm{RR}=0.88,95 \% \mathrm{CI}=0.74-1.06, \mathrm{P}=0.18>0.05)$. This phenomenon could be related to the type of disease; thus, we grouped the disease type to further study. Six randomized controlled studies ${ }^{21-24,27,29}$ of asthma with 2115 patients were used. The results showed no significant difference between the montelukast group and placebo group $(\mathrm{RR}=0.86,95 \% \mathrm{CI}=0.713-1.05, \mathrm{p}=0.13)$. Three randomized controlled studies ${ }^{24,25,29}$ of allergic rhinitis involving 993 patients were used, and the fixed-effect model combined with statistics showed that montelukast use did not lead to a significant increase in adverse events $(\mathrm{RR}=1.04,95 \% \mathrm{CI}=0.55-1.98, \mathrm{P}=0.91)$. We suggest that disease type does not have a significant correlation to montelukast and NEs. In addition, the most common neuropsychiatric adverse reaction, namely, "headache," was analyzed. Nine randomized controlled studies $^{1,21-27,31}$ involving 3393 patients were used, of which 2098 were in the montelukast group, and the rest were in the placebo group. The analysis showed that montelukast did not cause a significant increase in the incidence of headache. The results of the most common clinical NE, namely, "headache," were consistent with the overall results of the included study.

Aldea-Perona et $\mathrm{al}^{5}$ found age differences in the occurrence of NEs, and neuropsychiatric diseases were more common in children than in adults. As such, we conducted age grouping to analyze the role of age in the occurrence of NEs. The relationship between montelukast and NEs in children and adults was analyzed using the medical concept of adult age. The results showed RR of 0.87 and $95 \%$ CI of 0.71 to $1.06(\mathrm{P}=0.16)$. We cannot rule out the effect of age on the overall outcome. Most of the data collected by the pharmacovigilance institute were from children, whereas the majority of the patients in our study were adults. ${ }^{4-6,8,11-14}$ The study population is different from previous studies and may have a remarkable impact on the results.

Simultaneously, we analyzed the occurrence of adverse events in combination with montelukast and some commonly used drugs for rhinitis or asthma, such as loratadine/budesonide. Loratadine is an H1 receptor antagonist that is used in rhinitis and asthma. Our analysis showed that loratadine can significantly improve the symptoms of rhinitis and asthma when used in combination with montelukast. ${ }^{35}$ Budesonide is a hormone drug that combined with montelukast, and double dose of glucocorticoids showed similar improvement in patients. ${ }^{28}$ To clarify the relationship between montelukast and the occurrence of adverse mental events, we analyzed allergic rhinitis and asthma, respectively. Taking loratadine or inhalation of budesonide and montelukast in combination or alone, the occurrence of NEs was not statistically significant $(\mathrm{P}>0.05)$ in the montelukast group compared with the control group. Considering the effect of medication and the side effects of hormone drugs, combination medication may be more effective.

Based on our results, no significant association was found between montelukast and NE events in patients with rhinitis or asthma. We hypothesized whether the NE is related to the disease. Timonen et $\mathrm{al}^{36}$ and Kovacs $^{37}$ et al. found that people with allergies likely develop depression than healthy people. This finding may be due to the disorders of the hypothalamic pituitary-adrenal axis and sympathetic adrenal medulla 
systems and the changes in the secretion of cytokines in the body, which caused patients to be affected by emotional and behavioral factors in daily life, depression, and other neuropsychiatric adverse events. Asthma is a chronic disease, and the repeated attacks of the disease bring severe mental suffering to the patients. The inflammatory state in the body during the onset of asthma leads to an increase in pro-inflammatory cytokines, which are associated with the development of depression. ${ }^{38}$ In addition, animal studies have found that after increasing the cholinergic response in rats, rats likely develop tracheal constriction and airway inflammation, thereby increasing the occurrence of NEs. ${ }^{39,40}$ The abovementioned research indicates that NE may be caused by airway allergic disease. However, we were unable to carry out further research because of insufficient data.

All but one of the studies ${ }^{32}$ included in this paper were of good quality. The major funnel plots were symmetrical in appearance without evident publication bias Begg and Egger. Our meta-analysis showed no significant increase in the incidence of NEs in patients with allergic rhinitis and asthma compared with placebo $(\mathrm{P}>0.05)$.

This study has certain limitations. First, the effect of the disease on the results cannot be excluded. Second, considering that the study was not designed to report adverse drug reactions, no detailed record of their occurrence was found. Finally, the data of some pharmacovigilance research databases ${ }^{6,7,11-15,17}$ annot be combined and analyzed, which further reduce the reliability of the results of the article and affect the quality of the literature.

\section{CONFLICT OF INTEREST}

This work was supported by the National Natural Science Foundation of China (81670907) and the Natural Science Foundation of Shandong Province (ZR2019PH113).

\section{AUTHOR CONTRIBUTIONS}

Qing Song and Yakui Mou responsible for the collection of all relevant studies and responsible for the integrity of the data and the accuracy of the results. Research ideas and design:Qing Song, Yakui Mou and Xicheng Song. Interpret the data:Yao Yao and Yujuan Yang. Writing of the manuscript: Qing Song and Yakui Mou. Collect data analysis and related chart making:Hua Zhang and Yao Yao. Monitor the process of research and analysis and funding sources: Xicheng Song.

\section{Reference}

1. Baena-Cagnani CE, Berger WE, DuBuske LM, et al. Comparative effects of desloratadine versus montelukast on asthma symptoms and use of beta 2-agonists in patients with seasonal allergic rhinitis and asthma.International archives of allergy and immunology.2003;130(4):307-313.

2. Price DB, Hernandez D, Magyar P, et al. Randomised controlled trial of montelukast plus inhaled budesonide versus double dose inhaled budesonide in adult patients with asthma. Thorax.2003;58(3):211216.

3. Reiss TF, Chervinsky P, Dockhorn RJ, Shingo S, Seidenberg B, Edwards TB. Montelukast, a once-daily leukotriene receptor antagonist, in the treatment of chronic asthma: a multicenter, randomized, double-blind trial. Montelukast Clinical Research Study Group. Archives of internal medicine. 1998;158(11):1213-1220.

4. Aagaard L, Hansen EH. Paediatric adverse drug reactions following use of asthma medications in Europe from 2007 to 2011. Int J Clin Pharm. 2014;36(6):1222-1229.

5. Aldea Perona A, Garcia-Saiz M, Sanz Alvarez E. Psychiatric Disorders and Montelukast in Children: A Disproportionality Analysis of the VigiBase((R)). Drug safety. 2016;39(1):69-78.

6. Bygdell M, Brunlof G, Wallerstedt SM, Kindblom JM. Psychiatric adverse drug reactions reported during 
a 10-year period in the Swedish pediatric population. Pharmacoepidemiology and drug safety.2012;21(1):7986.

7. Callero-Viera A, Infante S, Fuentes-Aparicio V, Zapatero L, Alonso-Lebrero E. Neuropsychiatric reactions to montelukast. Journal of investigational allergology \&3 clinical immunology.2012;22(6):452-453.

8. Cereza G, Garcia Dolade N, Laporte JR. Nightmares induced by montelukast in children and adults. The European respiratory journal. 2012;40(6):1574-1575.

9. Ibarra-Barrueta O, Palacios-Zabalza I, Mora-Atorrasagasti O, Mayo-Suarez J. Effect of concomitant use of montelukast and efavirenz on neuropsychiatric adverse events. The Annals of pharmacotherapy.2014;48(1):145-148.

10. Kocyigit A, Gulcan Oksuz B, Yarar F, Uzun F, Igde M, Islek I. Hallucination development with montelukast in a child with asthma: case presentation. Iranian journal of allergy, asthma, and immunology.2013;12(4):397-399.

11. Lafay-Chebassier C, Chavant F, Favreliere S, Pizzoglio V, Perault-Pochat MC. Drug-induced Depression: a Case/Non Case Study in the French Pharmacovigilance Database. Therapie. 2015;70(5):425-432.

12. Mann PBLWGPSFSSRD. Pharmacosurveillance and safety of the leukotriene receptor antagonist (LTRA), montelukast. Clin Exp Allergy Rev. 2001:300-304.

13. Marchand MS, Jonville-Bera AP, Autret-Leca E. [Psychiatric disorders associated with montelukast: data from the National Pharmacovigilance Database]. Archives de pediatrie : organe officiel de la Societe francaise de pediatrie. 2013;20(3):269-273.

14. Wallerstedt SM, Brunlof G, Sundstrom A, Eriksson AL. Montelukast and psychiatric disorders in children. Pharmacoepidemiology and drug safety. 2009;18(9):858-864.

15. US Food and Drug Administration:FDA requires Boxed Warning about serious mental health side effects for asthma and allergy drug montelukast (Singulair). https://wwwfdagov/drugs.2020; accessed 1 March 2020.

16. US Food and Drug Administration:Early Communication about an ongoing safety review of montelukast (Singulair).http://wwwfdagov/Drugs 2008;accessed 1 March 2020.

17. US Food and Drug Administration:Updated information on leukotriene inhibitors: montelukast (marketed as Singulair), Zafirlukast (marketed as Accolate), and Zileuton (marketed as Zyflo and Zyflo CR).http://wwwfdagov/Drugs 2009; accessed 1 March 2020.

18. Narang R, Narang S, Narang D, Udeani G. Contemporary use of montelukast and its association with depression in asthma and allergic rhinitis patients. Chest. 2014;146(4):13A.

19. Jadad AR. Randomised Controlled Trials. 1998;London: BMJ Publishing Group.

20. Higgins J, Green S. Cochrane handbook for systematic reviews of interventions,v.5.1. Cochrane Collaboration Web site. 2011.

21. Knorr B, Matz J, Bernstein JA, et al. Montelukast for chronic asthma in 6- to 14-year-old children: a randomized, double-blind trial. Pediatric Montelukast Study Group. Jama. 1998;279(15):1181-1186.

22. Leff JA, Busse WW, Pearlman D, et al. Montelukast, a leukotriene-receptor antagonist, for the treatment of mild asthma and exercise-induced bronchoconstriction. The New England journal of medicine. 1998;339(3):147-152.

23. Noonan MJ, Chervinsky P, Brandon M, et al. Montelukast, a potent leukotriene receptor antagonist, causes dose-related improvements in chronic asthma. Montelukast Asthma Study Group. The European respiratory journal. 1998;11(6):1232-1239. 
24. Malmstrom K, Rodriguez-Gomez G, Guerra J, et al. Oral montelukast, inhaled beclomethasone, and placebo for chronic asthma. A randomized, controlled trial. Montelukast/Beclomethasone Study Group. Annals of internal medicine. 1999;130(6):487-495.

25. Meltzer EO, Malmstrom K, Lu S, et al. Concomitant montelukast and loratadine as treatment for seasonal allergic rhinitis: a randomized, placebo-controlled clinical trial. The Journal of allergy and clinical immunology. 2000;105(5):917-922.

26. Nayak AS, Philip G, Lu S, Malice MP, Reiss TF. Efficacy and tolerability of montelukast alone or in combination with loratadine in seasonal allergic rhinitis: a multicenter, randomized, double-blind, placebocontrolled trial performed in the fall. Annals of allergy, asthma 83 immunology : official publication of the American College of Allergy, Asthma, \& Immunology. 2002;88(6):592-600.

27. Baumgartner RA, Martinez G, Edelman JM, et al. Distribution of therapeutic response in asthma control between oral montelukast and inhaled beclomethasone. The European respiratory journal.2003;21(1):123128.

28. Yildirim Z, Ozlu T, Bulbul Y, Bayram H. Addition of montelukast versus double dose of inhaled budesonide in moderate persistent asthma. Respirology (Carlton, Vic). 2004;9(2):243-248.

29. Shah AR, Sharples LD, Solanki RN, Shah KV. Double-blind, randomised, controlled trial assessing controller medications in asthma. Respiration; international review of thoracic diseases.2006;73(4):449-456.

30. Clinical trial of low-dose theophylline and montelukast in patients with poorly controlled asthma. American journal of respiratory and critical care medicine. 2007;175(3):235-242.

31. Bisgaard H, Skoner D, Boza ML, et al. Safety and tolerability of montelukast in placebo-controlled pediatric studies and their open-label extensions. Pediatric pulmonology. 2009;44(6):568-579.

32. Prenner BM, Lu S, Danzig MR. Safety of fixed-dose loratadine/montelukast in subjects with allergic rhinitis. Allergy and asthma proceedings. 2010;31(6):493-498.

33. Bernstein JA. Allergic and mixed rhinitis: Epidemiology and natural history. Allergy and asthma proceedings. 2010;31(5):365-369.

34. Martinez FD, Vercelli D. Asthma. Lancet (London, England).2013;382(9901):1360-1372.

35. Dockhorn RJ, Bergner A, Connell JT, et al. Safety and efficacy of loratadine (Sch-29851): a new non-sedating antihistamine in seasonal allergic rhinitis. Annals of allergy. 1987;58(6):407-411.

36. Timonen M, Jokelainen J, Silvennoinen-Kassinen S, et al. Association between skin test diagnosed atopy and professionally diagnosed depression: a Northern Finland 1966 Birth Cohort study. Biological psychiatry. 2002;52(4):349-355.

37. Kovacs M, Stauder A, Szedmak S. Severity of allergic complaints: the importance of depressed mood. Journal of psychosomatic research.2003;54(6):549-557.

38. Eyre H, Baune BT. Neuroplastic changes in depression: a role for the immune system. Psychoneuroendocrinology. 2012;37(9):1397-1416.

39. Djuric VJ, Cox G, Overstreet DH, Smith L, Dragomir A, Steiner M. Genetically transmitted cholinergic hyperresponsiveness predisposes to experimental asthma. Brain, behavior, and immunity.1998;12(4):272-284.

40. Overstreet DH, Daws LC, Schiller GD, Orbach J, Janowsky DS. Cholinergic/serotonergic interactions in hypothermia: implications for rat models of depression. Pharmacology, biochemistry, and behavior. 1998;59(4):777-785.

Table 1 Characteristics of the included studies 


\begin{tabular}{|c|c|c|c|c|c|c|c|c|c|c|c|}
\hline Study & Design & Disease & $\begin{array}{l}\text { Age } \\
\text { (range, } \\
\text { years) }\end{array}$ & $\begin{array}{l}\text { Therapy } \\
\text { in } \\
\text { experi- } \\
\text { mental } \\
\text { group }\end{array}$ & $\begin{array}{l}\text { Therapy } \\
\text { in } \\
\text { control } \\
\text { group }\end{array}$ & Dosage & $\begin{array}{l}\text { Sample } \\
\text { size }\end{array}$ & $\begin{array}{l}\text { Sample } \\
\text { size }\end{array}$ & $\begin{array}{l}\mathrm{NE}^{+} \\
\text {sample } \\
\text { size }\end{array}$ & $\begin{array}{l}\mathrm{NE}^{+} \\
\text {sample } \\
\text { size }\end{array}$ & $\begin{array}{l}\mathrm{NE}^{+} \\
\text {type } \\
\text { and } \\
\text { sample } \\
\text { size }\end{array}$ \\
\hline & & & & & & & \multicolumn{2}{|c|}{ ExperimentEolntrol } & \multicolumn{2}{|c|}{ ExperimentEøhtrol } & \\
\hline $\begin{array}{l}\text { Jonathan } \\
1998\end{array}$ & $\mathrm{RCT}^{++}$ & asthma & $\begin{array}{l}15 \text { to } \\
45 \\
\text { vears }\end{array}$ & \multicolumn{2}{|c|}{ Montelukaßlacebo } & $10 \mathrm{mg}$ & 54 & 56 & 11 & 18 & Headache1 \\
\hline $\begin{array}{l}\text { Knorr } \\
1998\end{array}$ & $\mathrm{RCT}^{++}$ & asthma & $\begin{array}{l}6-14- \\
\text { years }\end{array}$ & \multicolumn{2}{|c|}{ Montelukaßlacebo } & $5 \mathrm{mg}$ & 201 & 135 & 38 & 29 & Headache 3 \\
\hline $\begin{array}{l}\text { Noonan } \\
1998\end{array}$ & $\mathrm{RCT}^{++}$ & asthma & $\begin{array}{l}18-65 \\
\text { yrears }\end{array}$ & \multicolumn{2}{|c|}{ Montelukaßlacebo } & \multicolumn{2}{|c|}{$2 \mathrm{mg} / 10 \mathrm{mg} / \mathrm{5l}) \mathrm{mg}$} & 69 & 18 & 10 & $18 / 10$ \\
\hline $\begin{array}{l}\text { Theodore } \\
1998\end{array}$ & $\mathrm{RCT}^{++}$ & asthma & $\begin{array}{l}{[?] 15} \\
\text { years }\end{array}$ & \multicolumn{2}{|c|}{ MontelukaBtacebo } & $10 \mathrm{mg}$ & 408 & 273 & 75 & 61 & Headache7. \\
\hline $\begin{array}{l}\text { Malmstro } \\
1999\end{array}$ & $\mathrm{RCT}^{++}$ & asthma & $\begin{array}{l}{[?] 15} \\
\text { years }\end{array}$ & \multicolumn{2}{|c|}{ Montelukaßtacebo } & $10 \mathrm{mg}$ & 387 & 257 & 68 & 40 & Headache6 \\
\hline $\begin{array}{l}\text { Meltzer } \\
2000-1\end{array}$ & $\mathrm{RCT}^{++}$ & $\begin{array}{l}\text { Allergic } \\
\text { rhinitis }\end{array}$ & $\begin{array}{l}15-75 \\
\text { years }\end{array}$ & \multicolumn{2}{|c|}{ MontelukaBlacebo } & $10 \mathrm{mg}$ & 185 & 91 & 12 & 6 & Headache1 \\
\hline $\begin{array}{l}\text { Meltzer } \\
2000-2\end{array}$ & $\mathrm{RCT}^{++}$ & $\begin{array}{l}\text { Allergic } \\
\text { rhinitis }\end{array}$ & $\begin{array}{l}15-75 \\
\text { years }\end{array}$ & \multicolumn{4}{|c|}{$\begin{array}{l}\text { Montelukakiofratadinel0mg+10n@g: } 10 \mathrm{mg} \\
\text { Loratadine }\end{array}$} & 92 & 1 & 8 & Headache1 \\
\hline $\begin{array}{l}\text { Anjuli } \\
2002-1\end{array}$ & $\mathrm{RCT}^{++}$ & $\begin{array}{l}\text { Allergic } \\
\text { rhinitis }\end{array}$ & $\begin{array}{l}15-85 \\
\text { years }\end{array}$ & \multicolumn{2}{|c|}{ Montelukaptacebo } & $10 \mathrm{mg}$ & 155 & 149 & 5 & 7 & Headache5 \\
\hline $\begin{array}{l}\text { Anjuli } \\
2002-2\end{array}$ & $\mathrm{RCT}^{++}$ & $\begin{array}{l}\text { Allergic } \\
\text { rhinitis }\end{array}$ & $\begin{array}{l}15-85 \\
\text { years }\end{array}$ & \multicolumn{4}{|c|}{$\begin{array}{l}\text { Montelukakitofratadine10mg+10n30210mg } \\
\text { Loratadine }\end{array}$} & 301 & 9 & 12 & Headache9 \\
\hline $\begin{array}{l}\text { Baumgart } \\
2003\end{array}$ & $\tan \mathrm{CT}^{++}$ & asthma & $\begin{array}{l}{[?] 15} \\
\text { years }\end{array}$ & \multicolumn{2}{|c|}{ Montelukaßlacebo } & $10 \mathrm{mg}$ & 313 & 103 & 31 & 18 & Headache3t \\
\hline $\begin{array}{l}\text { CarlosE } \\
2003\end{array}$ & $\mathrm{RCT}^{++}$ & $\begin{array}{l}\text { Allergic } \\
\text { rhinitis } \\
\text { and } \\
\text { asthma }\end{array}$ & $\begin{array}{l}{[?] 15} \\
\text { years }\end{array}$ & Montelul & raBtacebo & $10 \mathrm{mg}$ & 311 & 302 & 11 & 11 & Headache1 \\
\hline $\begin{array}{l}\text { YildirimI } \\
2004\end{array}$ & $\mathrm{RCT}^{++}$ & asthma & \multicolumn{6}{|c|}{$\begin{array}{l}\text { mean:36.93ontelukaBux/Besdnsidzolheg }+40015 \\
\pm \quad \text { mg:800mg } \\
2.98\end{array}$} & 2 & 0 & Headache 2 \\
\hline $\begin{array}{l}\text { Charles } \\
2006\end{array}$ & $\mathrm{RCT}^{++}$ & asthma & $\begin{array}{l}{[?] 15} \\
\text { years }\end{array}$ & \multicolumn{2}{|c|}{ Montelukaßlacebo } & $10 \mathrm{mg}$ & 164 & 164 & 34 & 36 & nervousnes \\
\hline $\begin{array}{l}\text { Shah } \\
2006\end{array}$ & $\mathrm{RCT}^{++}$ & asthma & $\begin{array}{l}18-60 \\
\text { years }\end{array}$ & \multicolumn{5}{|c|}{ MontelukaBux/Besdasidz(0)heg + 200ß0g:400mg30 } & 1 & 0 & Headachels \\
\hline $\begin{array}{l}\text { Bisgaard } \\
2009\end{array}$ & $\mathrm{RCT}^{++}$ & $\begin{array}{l}\text { Allergic } \\
\text { rhinitis }\end{array}$ & $\begin{array}{l}2-14 \\
\text { years }\end{array}$ & \multicolumn{2}{|c|}{ Montelukaßtacebo } & $5 \mathrm{mg}$ & 280 & 133 & 9 & 2 & Headache 9 \\
\hline $\begin{array}{l}\text { Bruce } \\
2010-1\end{array}$ & $\mathrm{RCT}^{++}$ & asthma & $\begin{array}{l}15-92 \\
\text { years }\end{array}$ & \multicolumn{2}{|c|}{ MontelukaBtacebo } & $\begin{array}{l}10 \mathrm{mg} \\
\text { or } \\
20 \mathrm{mg}\end{array}$ & 555 & 1111 & 6 & 19 & Headache6 \\
\hline $\begin{array}{l}\text { Bruce } \\
2010-2\end{array}$ & $\mathrm{RCT}^{++}$ & asthma & $\begin{array}{l}15-92 \\
\text { years }\end{array}$ & \multicolumn{4}{|c|}{$\begin{array}{l}\text { Montelukakitopratadind } 0 \mathrm{mg}+10 \mathrm{n} 96910 \mathrm{mg} \\
\text { Loratadine }\end{array}$} & 971 & 66 & 85 & $\begin{array}{l}\text { Nervous } \\
\text { system } \\
\text { disor- } \\
\text { ders66/85; } \\
\text { Headache3 } \\
\text { Somnolenc }\end{array}$ \\
\hline
\end{tabular}


${ }^{+} \mathrm{NE}:$ Neuropsychiatric event; ${ }^{++} \mathrm{RCT}$ :randomized controlled trial

Table 2 Quality assessment of individual study

\begin{tabular}{|c|c|c|c|c|c|c|c|c|}
\hline Study & $\begin{array}{l}\text { Allocation } \\
\text { sequence } \\
\text { generation }\end{array}$ & $\begin{array}{l}\text { Allocation } \\
\text { concealment }\end{array}$ & Blinding & $\begin{array}{l}\text { Lost to } \\
\text { follow-up }\end{array}$ & $\begin{array}{l}\text { Calculation } \\
\text { of sample } \\
\text { size }\end{array}$ & $\begin{array}{l}\text { Statistical } \\
\text { analysis }\end{array}$ & $\begin{array}{l}\text { Level of } \\
\text { quality }\end{array}$ & $\begin{array}{l}\mathrm{ITT}^{++} \\
\text {analysis }\end{array}$ \\
\hline $\begin{array}{l}\text { Jonathan } \\
1998\end{array}$ & $\mathrm{~B}$ & $\mathrm{~A}$ & $\mathrm{~A}$ & 1 & Yes & $\begin{array}{l}\text { ANOVA + } \\
\text { Fisher's } \\
\text { exact test }\end{array}$ & $\mathrm{B}$ & Yes \\
\hline Knorr 1998 & $\mathrm{~A}$ & $\mathrm{~A}$ & $\mathrm{~A}$ & 2 & Yes & $\begin{array}{l}\text { ANOVA + } \\
\text { Shapiro- } \\
\text { Wilks test } \\
\text { Cochran- } \\
\text { Mantel- } \\
\text { Haenszel } \\
\text { test }\end{array}$ & A & Yes \\
\hline $\begin{array}{l}\text { Noonan } \\
1998\end{array}$ & $\mathrm{~A}$ & $\mathrm{~A}$ & $\mathrm{~A}$ & 0 & Yes & $\begin{array}{l}\text { ANOVA + } \\
\text { Fisher's } \\
\text { exact } \\
\text { Cochran- } \\
\text { Mantel- } \\
\text { Haenszel } \\
\text { test } \\
\text { Tukey's } \\
\text { modified } \\
\text { linear trend } \\
\text { test } \\
\text { (stepwise } \\
\text { trend test) }\end{array}$ & A & Yes \\
\hline $\begin{array}{l}\text { Malmstrom } \\
1999\end{array}$ & $\mathrm{~A}$ & $\mathrm{~A}$ & A & 13 & Yes & $\begin{array}{l}\text { ANOVA + } \\
\text { Dunnet-- } \\
\text { Tamhane } \\
\text { approach, } \\
\text { Shapiro-- } \\
\text { Wilk } \\
\text { statis- } \\
\text { tic,Levene } \\
\text { test }\end{array}$ & A & No \\
\hline $\begin{array}{l}\text { Meltzer } \\
2000-1\end{array}$ & $\mathrm{~A}$ & $\mathrm{~A}$ & A & 4 & Yes & $\begin{array}{l}\text { ANOVA + } \\
\text { Fisher } \\
\text { exact test } \\
\text { Cochran- } \\
\text { Mantel- } \\
\text { Haenszel } \\
\text { test; }\end{array}$ & A & No \\
\hline
\end{tabular}




\begin{tabular}{|c|c|c|c|c|c|c|c|c|}
\hline Study & $\begin{array}{l}\text { Allocation } \\
\text { sequence } \\
\text { generation }\end{array}$ & $\begin{array}{l}\text { Allocation } \\
\text { concealment }\end{array}$ & Blinding & $\begin{array}{l}\text { Lost to } \\
\text { follow-up }\end{array}$ & $\begin{array}{l}\text { Calculation } \\
\text { of sample } \\
\text { size }\end{array}$ & $\begin{array}{l}\text { Statistical } \\
\text { analysis }\end{array}$ & $\begin{array}{l}\text { Level of } \\
\text { quality }\end{array}$ & $\begin{array}{l}\mathrm{ITT}^{++} \\
\text {analysis }\end{array}$ \\
\hline $\begin{array}{l}\text { Meltzer } \\
2000-2\end{array}$ & $\mathrm{~A}$ & $\mathrm{~A}$ & $\mathrm{~A}$ & 4 & Yes & $\begin{array}{l}\text { ANOVA }+ \\
\text { Fisher } \\
\text { exact test } \\
\text { Cochran- } \\
\text { Mantel- } \\
\text { Haenszel } \\
\text { test; }\end{array}$ & $\mathrm{A}$ & No \\
\hline $\begin{array}{l}\text { Anjuli } \\
2002-1\end{array}$ & $\mathrm{~A}$ & $\mathrm{~A}$ & $\mathrm{~A}$ & 3 & Yes & $\begin{array}{l}\text { ANOVA + } \\
\text { Wilcoxon } \\
\text { rank sum } \\
\text { test }\end{array}$ & A & Yes \\
\hline $\begin{array}{l}\text { Anjuli } \\
2002-2\end{array}$ & $\mathrm{~A}$ & $\mathrm{~A}$ & A & 3 & Yes & $\begin{array}{l}\text { ANOVA + } \\
\text { Wilcoxon } \\
\text { rank sum } \\
\text { test }\end{array}$ & A & Yes \\
\hline $\begin{array}{l}\text { Baumgartner } \\
2003\end{array}$ & $\mathrm{~A}$ & $\mathrm{~A}$ & A & NA & Yes & $\begin{array}{l}\text { ANOVA } \\
+\end{array}$ & $\mathrm{A}$ & Yes \\
\hline $\begin{array}{l}\text { CarlosE } \\
2003\end{array}$ & $\mathrm{~A}$ & A & A & 0 & Yes & $\begin{array}{l}\text { ANOVA } \\
+\end{array}$ & A & Yes \\
\hline $\begin{array}{l}\text { YildirimI } \\
2004\end{array}$ & A & $\mathrm{A}$ & B & 0 & Yes & $\begin{array}{l}\text { Mann-- } \\
\text { Whitney } \\
U \text {-test }\end{array}$ & B & No \\
\hline $\begin{array}{l}\text { Charles } \\
2006\end{array}$ & $\mathrm{~A}$ & $\mathrm{~A}$ & A & NA & Yes & $\begin{array}{l}\text { Huber- } \\
\text { White } \\
\text { variance; } \\
\text { Linear and } \\
\text { logistic } \\
\text { regression } \\
\text { models }\end{array}$ & $\mathrm{A}$ & Yes \\
\hline $\begin{array}{l}\text { Shah } \\
2006\end{array}$ & $\mathrm{~A}$ & $\mathrm{~A}$ & A & 0 & Yes & $\begin{array}{l}\text { ANOVA } \\
+\end{array}$ & $\mathrm{A}$ & Yes \\
\hline $\begin{array}{l}\text { Bisgaard } \\
2009\end{array}$ & B & B & A & 0 & Yes & $\begin{array}{l}\text { Fisher's } \\
\text { exact } \\
\text { test }\end{array}$ & B & No \\
\hline $\begin{array}{l}\text { Bruce } \\
2010-1\end{array}$ & B & B & $\mathrm{C}$ & 9 & Yes & $\mathrm{NA}^{\S}$ & $\mathrm{C}$ & No \\
\hline $\begin{array}{l}\text { Bruce } \\
2010-2\end{array}$ & B & B & $\mathrm{C}$ & 13 & Yes & $\mathrm{NA}^{\S}$ & $\mathrm{C}$ & No \\
\hline
\end{tabular}

A, low risk of bias:the study met almost criteria; B, moderate risk of bias :the study met part or unclear for one or more quality criteria; $\mathrm{C}$, high risk of bias :the study was not met or included criteria; ${ }^{+}$ANOVA:analysis of variance; ${ }^{++}$ITT:Intention-to-treat; ${ }^{\S} \mathrm{NA}$ : not available;

Figure 1. PRISMA flow diagram demonstrating the progress of study evaluation throughout the review.

Figure 2 . Forest plots of (A):the relationship between patient with asthma or allergic rhinitis use montelukast and the occurrence of neuropsychiatric events and (B): funnel plot of the included studies.

Figure 3 . Forest plots of patients with asthma or rhinitis have been linked to a neuropsychiatric event 
called headache

Figure 4 . Forest plots of (A):the relationship between the use of montelukast and neuropsychiatric events in asthma patients and(B)the relationship between the use of montelukast and neuropsychiatric events in patients with rhinitis.

Figure 5 . Forest plots of (A):the relationship between montelukast and neuropsychiatric events in adult patients with asthma or rhinitis and (B): the relationship between montelukast and neuropsychiatric events in children patients with asthma or rhinitis.

Figure 6 . Funnel plot of(A):the included studies based on the patient with montelukast or common clinical drugs analysis and forest plots of (B):the neuropsychiatric events between montelukast and budesonide versus budesonide alone in asthmatic patients and $(\mathrm{C})$ : the occurrence of neuropsychiatric events in patients with allergic rhinitis compared with montelukast combined with loratadine versus loratadine alone

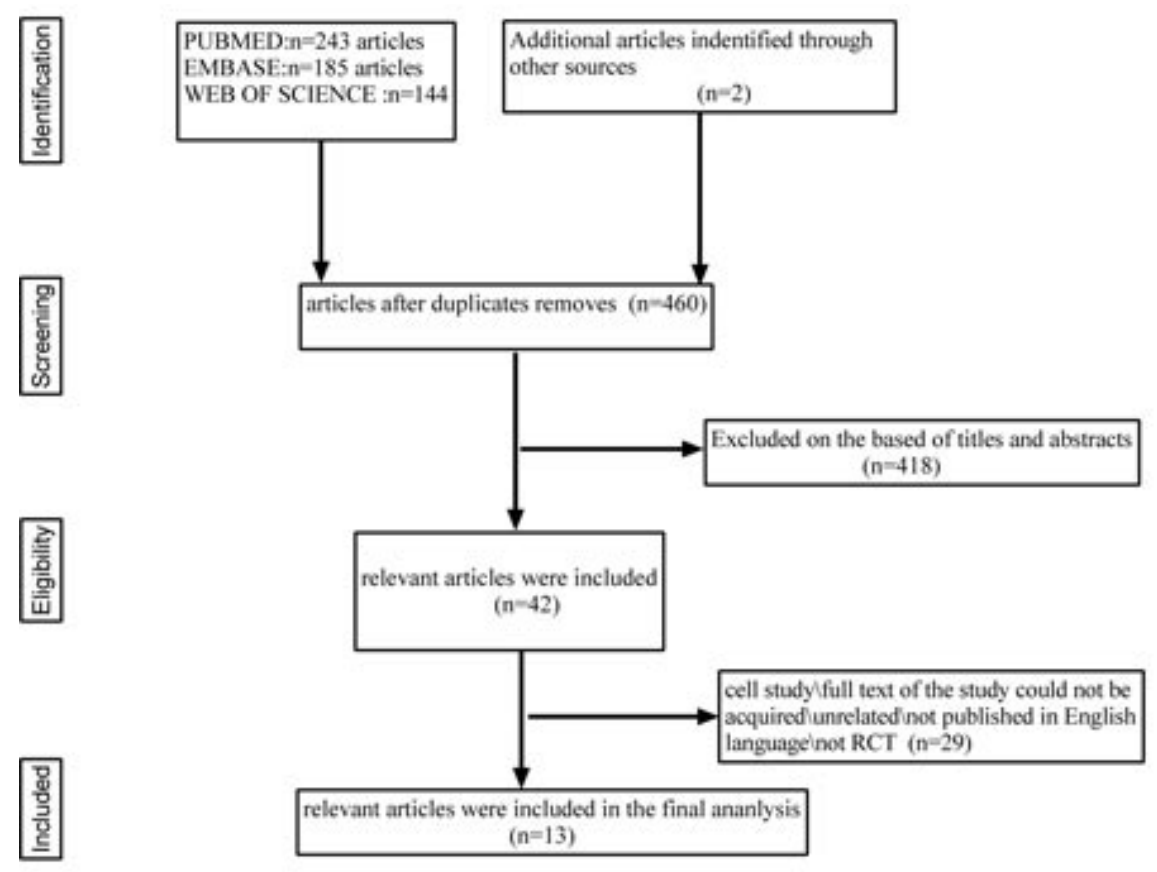




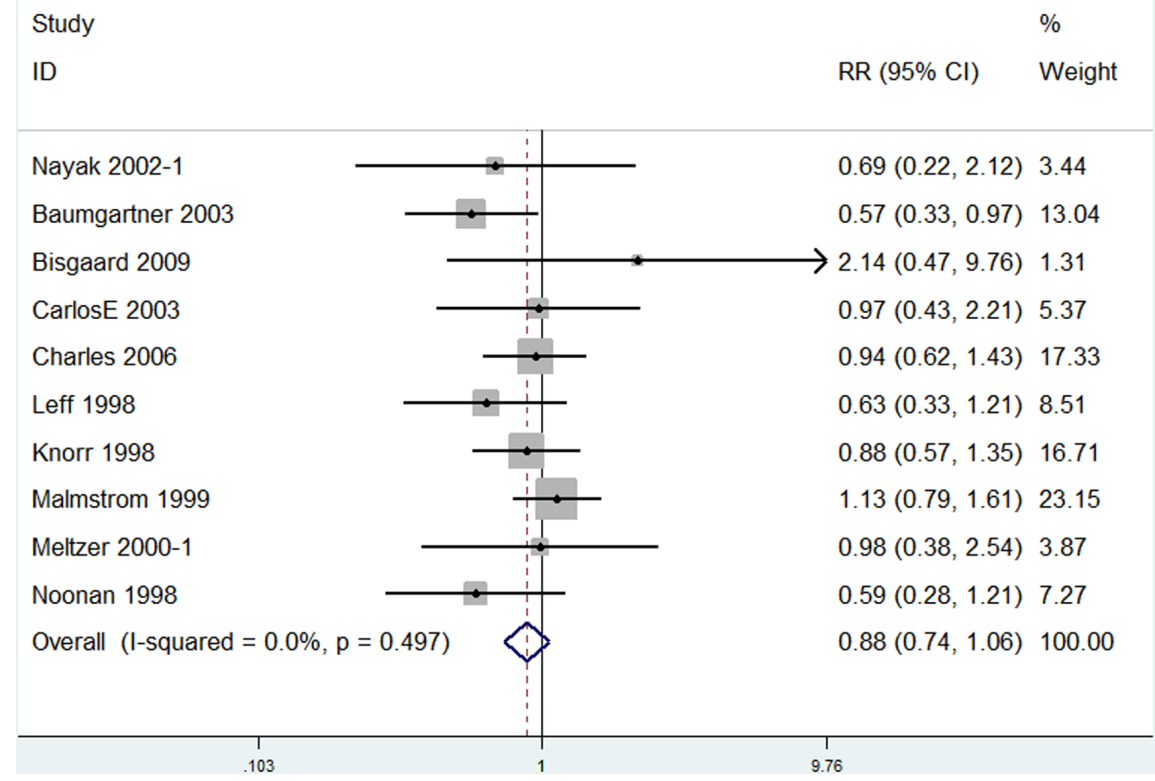

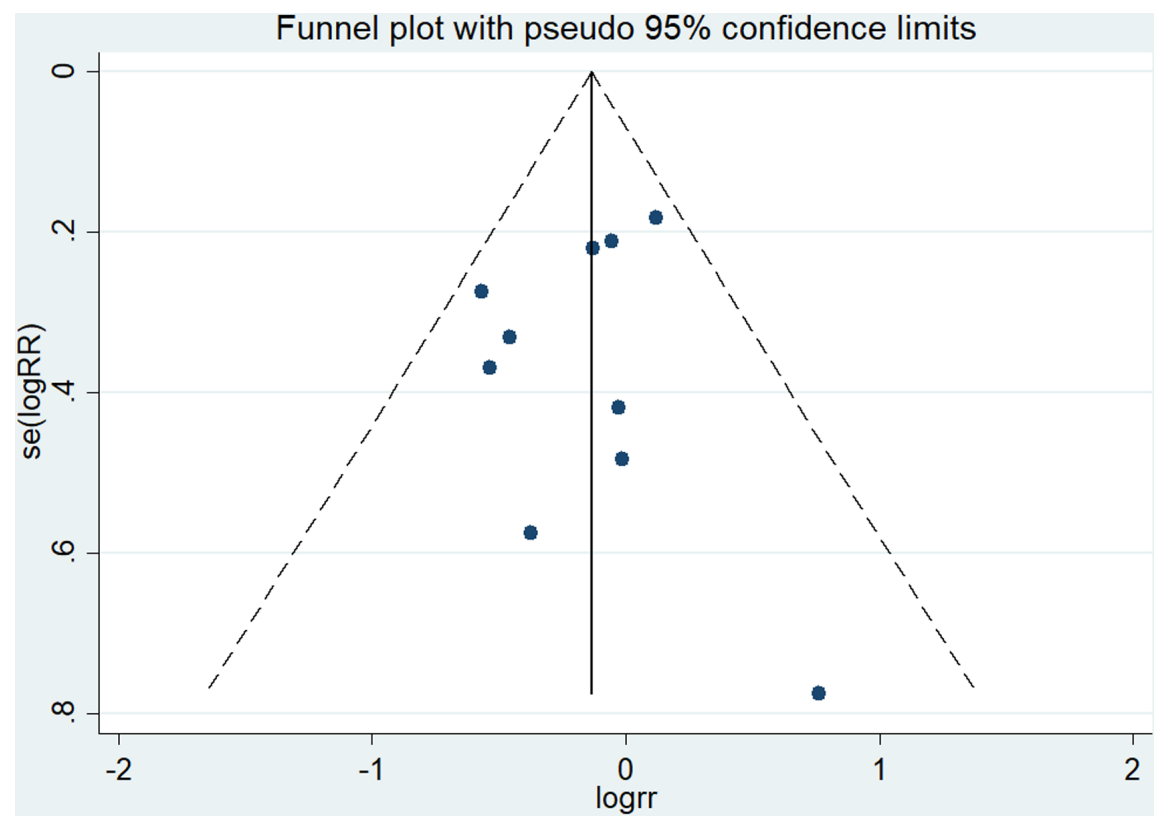


Study

ID

.

Nayak 2002-1

Baumgartner 2003

Bisgaard 2009

CarlosE 2003

Leff 1998

Knorr 1998.

Malmstrom 1999

Meltzer 2000-1

Noonan 1998

Overall $(\mathrm{I}$-squared $=2.6 \%, \mathrm{p}=0.413$ )
$\%$

RR $(95 \% \mathrm{Cl}) \quad$ Weight
$0.69(0.22,2.12) \quad 4.16$

$0.57(0.33,0.97) 15.78$

$\rightarrow 2.14(0.47,9.76) 1.58$

$0.97(0.43,2.21) \quad 6.50$

$0.63(0.33,1.21) \quad 10.29$

$0.88(0.57,1.35) \quad 20.21$

$1.13(0.79,1.61) 28.00$

$0.98(0.38,2.54) \quad 4.69$

$0.59(0.28,1.21) 8.79$

$0.87(0.71,1.06) \quad 100.00$
Study

ID
$\%$

RR $(95 \% \mathrm{Cl}) \quad$ Weight

$0.57(0.33,0.97) \quad 15.16$

$0.94(0.62,1.43) \quad 20.15$

$0.63(0.33,1.21) \quad 9.89$

$0.88(0.57,1.35) \quad 19.42$

$1.13(0.79,1.61) \quad 26.91$

$0.59(0.28,1.21) \quad 8.45$

$0.86(0.71,1.05) \quad 100.00$ 
RR $(95 \% \mathrm{Cl}) \quad$ Weight

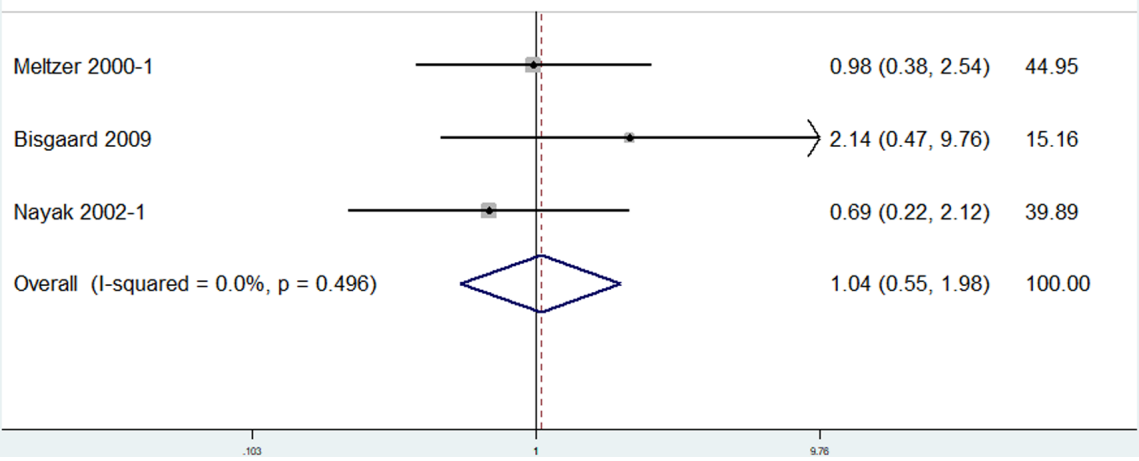

Study

ID

RR $(95 \% \mathrm{Cl}) \quad$ Weight

\begin{tabular}{|c|c|c|}
\hline Nayak 2002-1 & $0.69(0.22,2.12)$ & 4.19 \\
\hline Baumgartner 2003 & $0.57(0.33,0.97)$ & 15.91 \\
\hline CarlosE 2003 & $0.97(0.43,2.21)$ & 6.56 \\
\hline Charles 2006 & $0.94(0.62,1.43)$ & 21.14 \\
\hline Jonathan 1998 & $0.63(0.33,1.21)$ & 10.38 \\
\hline Malmstrom 1999 & $1.13(0.79,1.61)$ & 28.23 \\
\hline Meltzer 2000-1 & $0.98(0.38,2.54)$ & 4.72 \\
\hline Noonan 1998 & $0.59(0.28,1.21)$ & 8.86 \\
\hline Overall (I-squared $=0.0 \%, p=0.429$ ) & $0.87(0.71,1.06)$ & 100.00 \\
\hline
\end{tabular}


Study

ID
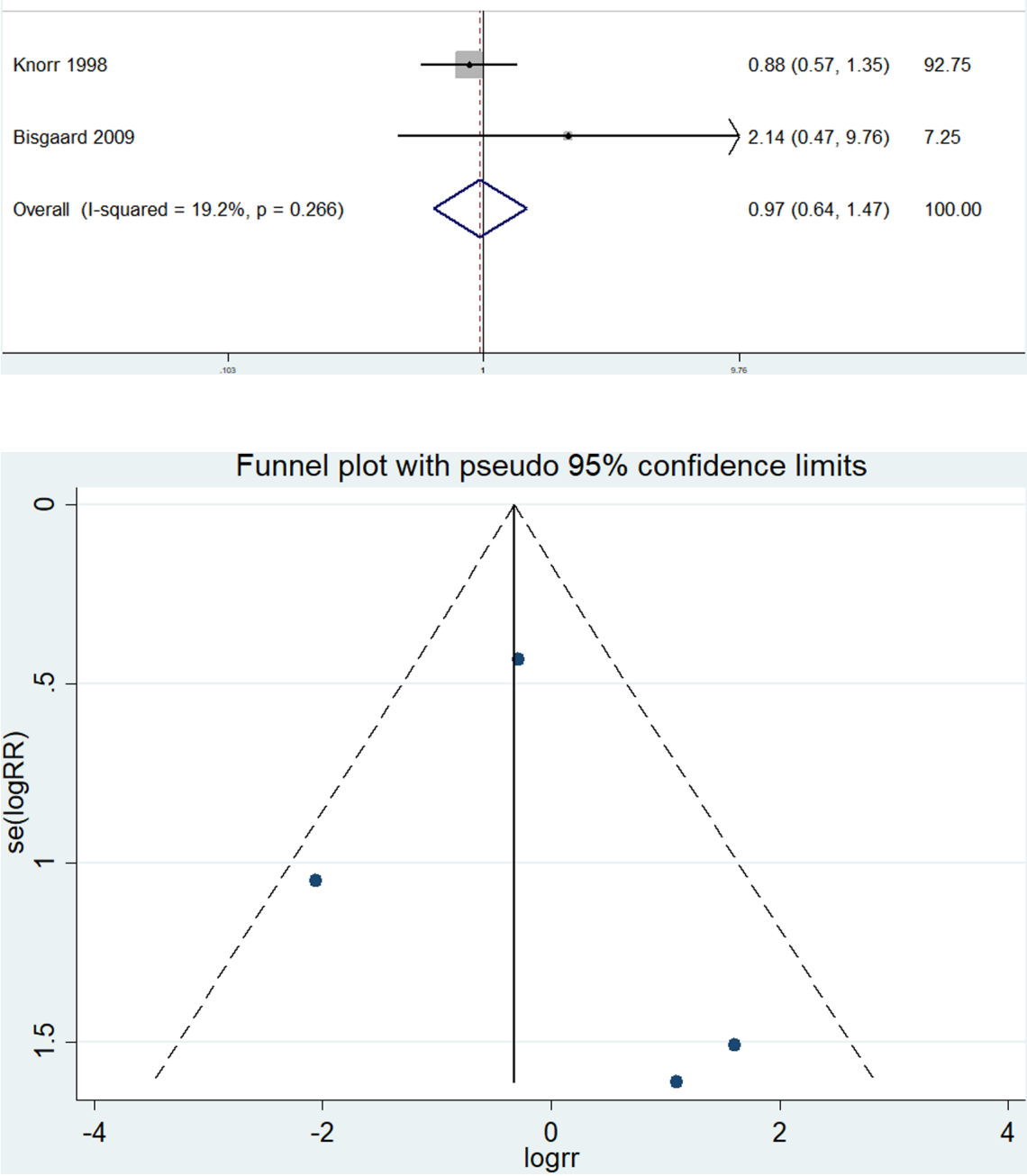
Study

ID

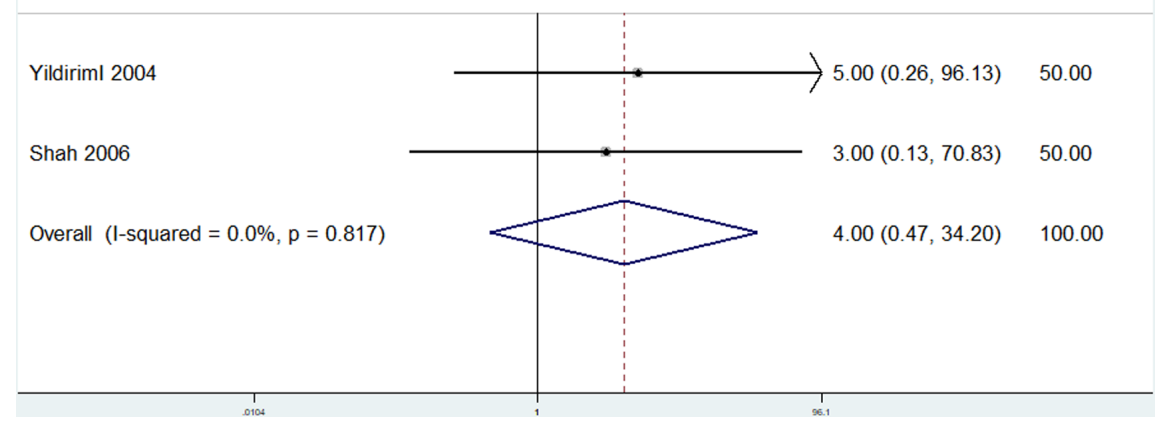

Study

ID

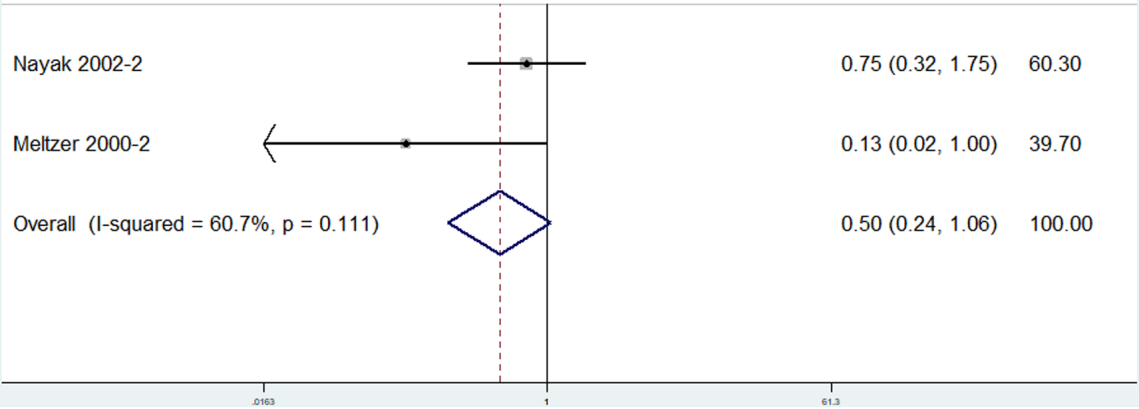

